\title{
Backing Despots? Foreign Aid and the Survival of Autocratic Regimes
}

\author{
Camilo Nieto-Matiz (1) and Luis L. Schenoni \\ Department of Political Science, University of Notre Dame, Notre Dame, IN, United States
}

\begin{abstract}
What is the effect of foreign aid on the survival of autocratic regimes? Extant work about the effect of foreign aid on the recipient's political regime has come to contradictory conclusions. Current findings display the full spectrum of possibilities from a democratizing effect to the enhancement of authoritarian survival. While some studies suggest that foreign aid strengthen autocrats and their incentives to cling to power, others have focused on specific periods and donors, thus finding a democratizing effect of foreign aid. In this article, we argue that the effect of foreign aid on autocratic survival does not operate in a direct way, but it is conditional on the levels of political leverage exerted by democratic donors vis-à-vis the autocratic leaders. This leverage, we find, is defined by the capability of democratic donors to back conditionality with effective political pressure. More specifically, we find that given similar levels of aid, autocratic recipients that are highly dependent on the United States-a quintessential democratic donor with extensive political influence-have a shorter survival rate when compared to those with which the United States has weaker ties and thus lower leverage.
\end{abstract}

\section{KEYWORDS}

Foreign aid; autocratic survival; democratic leverage

\section{Introduction}

The literature about the effects of foreign aid on the recipient's political regime has expanded considerably, though inconsistently, in the last decades. While some have emphasized the anti-authoritarian effect of certain types of aid, ${ }^{1}$ others have highlighted that, more generally, aid helps dictators stay longer in power. ${ }^{2}$ Adding to this puzzle, scholars have even found that aid stabilizes both democracies and autocracies ${ }^{3}$ and that it has no effect whatsoever. ${ }^{4}$

Our review of extant literature reveals that these inconsistencies, and even contradictions, might be due to different methodological choices regarding regional and temporal scope, characteristics of donor and recipient countries,

\section{CONTACT Camilo Nieto-Matiz cnietoma@nd.edu Department of Political Science, University of Notre} Dame, 2003 Nanovic Hall, Notre Dame, IN 46556

Luis L. Schenoni is currently an Assistant Professor at the International Studies Division, Centro de Investigación y Docencia Económicas (CIDE), Mexico City. 
and definitions of the independent (aid) and dependent (regime type) variables. In this article, we develop an argument that makes sense of these conflicting findings. A big-picture evaluation of the literature suggests that anti-authoritarian effects are often found when democratic donors are powerful in a particular place and time period. We argue that the effects of aid on the survival of autocratic regimes are conditional on the leverage that democratic donors have vis-à-vis the autocratic coalition of the recipient country. This leverage is, in turn, defined by the capability of democratic donors to back conditionality with effective pressure. More specifically, we argue that aid reduces the survival rate of autocratic recipients when they are highly dependent on democratic aid or are under the strategic clout of the United States-a quintessential democratic donor with far-reaching political ties. Conversely, aid should increase the chances of survival of autocratic recipients when democracies have lower leverage against them.

We test our arguments in a larger setting using the Geddes, Wright, and Frantz (GWF) cross-national data set of all autocratic regimes between 1946 and 2010. We use Cox proportional hazards to model the duration of autocratic regimes depending on the levels of Official Development Assistance (ODA) they receive. We focus on autocratic survival as our dependent variable, which means we face the additional challenge of finding anti-authoritarian effects in a type of design that has consistently rendered the opposite results in previous research. Our findings are broadly in line with our expectations and hold important implications for the future of democracy promotion in a world where liberal democracies are steadily losing leverage to powerful international autocracies such as China. ${ }^{5}$

This article is organized as follows. First, we review the literature on the relationship between foreign aid and the recipient's regime type. Second, we present our theoretical argument. Third, we describe the data sources and the statistical model, and we discuss the empirical results. We finish with some concluding remarks and practical implications.

\section{Foreign aid and regime survival: Previous literature}

Ever since Lawrence Whitehead's ${ }^{6}$ seminal work, the field of democratization has expanded beyond the borders of the nation-state seeking for the international determinants of democratic transitions and breakdowns. Most scholars now agree that international factors are key to understanding regime change in myriad ways. Within this broad research agenda, many have been focusing on how foreign aid can promote regime stability or change, either through a diffusion mechanism or a hegemonic mechanism by which stronger states further their regime preferences abroad. ${ }^{7}$

The existing literature on this topic has produced mixed results: whereas some studies have generated optimistic findings regarding the antiauthoritarian role of foreign aid, a different set of studies has been skeptical 
about the role of aid in promoting autocratic breakdowns. Among the first set of studies, Finkel, Pérez-Liñán, and Seligson ${ }^{8}$ suggest that foreign assistance promotes democratization by generating the structural conditions that facilitate democratic transitions, and by empowering democratic entrepreneurs in the domestic arena. ${ }^{9}$ The authors find a clear and consistent impact of USAID democracy assistance on levels of democracy in recipient countries from 1990 to 2003. More specifically, "an investment of one million dollars would foster an increase in democracy $65 \%$ greater than the change expected for the average country in the sample in any given year." ${ }^{10}$ This design was replicated extending the series slightly back in time to $1988^{11}$ and $1972^{12}$ yielding similar results.

The findings of the optimists, however, seem to be considerably bounded by donor, space, and time. Knack ${ }^{13}$ shows that, unlike USAID, ODA does not have a significant effect in a comparable time period (1990-2010), and prodemocratic outcomes are even less probable if one goes back in time (1975-2010). The extent of regional scope also seems to bound these results. In the partially overlapping regions of the Arab world ${ }^{14}$ and Muslim majority countries, ${ }^{15}$ for instance, the effect of aid, both coming from the United States and other democratic donors, is negative. Finally, some have proposed that characteristics of the recipients might also prevent pro-democratic effects of aid from taking place. ${ }^{16}$

Another set of studies has found that, under more general conditions, foreign aid can prolong the life of autocracies. ${ }^{17}$ If autocratic leaders wish to remain in power, they must retain the support of their winning political coalition, and, to this purpose, foreign aid provides autocrats a way to keep potential defectors satisfied. There are two main ways in which foreign aid may contribute to autocratic survival: first, rulers can use foreign aid to prop up the autocratic regime indirectly, by distributing pork among political groups, coopting the opposition, or simply taking credit for the expansion of infrastructure and public services. Even under external pressure, autocrats can raise their prospects of survival by introducing pseudo-democratic institutions, such as autocratic parties and legislatures, and using foreign aid to skew the playing field. Second, autocrats can use foreign aid to tighten their grip on power more directly, distributing this rent within the authoritarian coalition or financing repression by enlarging, rewarding, and better equipping the police and military. ${ }^{18}$

The chasm between the empirical findings of skeptics and optimists in large- $n$ designs is driven, in our consideration, by disagreements regarding the type of aid to be considered, how to conceptualize regime change, and what should be regarded as a proper geographic and temporal scope. Skeptics such as Kono and Montinola, for instance, cover the period from 1960 to 1999 , finding that ODA increases the probability that an autocratic recipient will survive in power. ${ }^{19}$ Studies that focus on almost the same time period (post-World War II), type of aid (ODA), and dependent variable (autocratic 
survival) tend to reach, not surprisingly, very similar conclusions. ${ }^{20}$ Conversely, studies that focus on a different time period (the late or postCold War period), type of aid (USAID), and dependent variable (level of democracy) reach the opposite conclusions. ${ }^{21}$ Case studies that highlight prodemocratic effects also tend to be clustered in particular regions such as East Asia, Latin America, and sub-Saharan Africa, ${ }^{22}$ but they are conspicuous by their absence in others.

At first sight, this state of the art suggests that the effect of foreign aid on political regimes is mixed, as it can strengthen both democratic and authoritarian regimes depending on other factors. ${ }^{23}$ On second consideration, however, these divergencies do offer a hint on how to move forward. More positive results are often found when the donor is a powerful democracy such as the United States, promoting democracy in its geographic vicinities. In the next section, we use this insight to provide a theoretical framework that brings both camps together.

\section{Theoretical framework: Foreign aid and autocratic survival}

What is the effect of foreign aid on the survival of autocratic regimes? We argue that the effect of foreign aid on autocratic survival does not operate in a direct way, but it is conditional on the levels of political leverage exerted by democratic donors vis-à-vis the autocratic leaders. While unearned incomesuch as foreign aid-can be used by autocrats as a source of financial and political strength, democratic donors may offset such effect by imposing effective conditionalities on the use of foreign aid. Democratic leverage, we argue, is a key in making conditionality an effective tool.

Autocrats may strengthen their political survival and bolster the regime's durability as external financial resources come into their hands. Through foreign aid, autocrats are able to positively affect the political regime's survival rate, by increasing state strength and resources for political repression; lowering the incentives to tax the population; and using resources for patronage politics. ${ }^{24}$ This is consistent with a broader literature suggesting that "unearned income" such as foreign aid, ${ }^{25}$ oil wealth, ${ }^{26}$ and international loans ${ }^{27}$ can be channeled in ways that increase regime duration.

Yet leaders of autocratic regimes face constraints on their actions. Because the politics of aid allocation resembles a strategic game of asymmetric information, donors anticipate that autocratic leaders may have incentives to discretionally use such resources for clinging to power. Consequently, democratic donors may impose restrictions on autocracies in order to thwart discretional spending and restrict the allocation of aid for specific purposes. Democratic donors, in turn, differ in their capacity to effectively enforce these conditionalities depending on their economic and political clout. Building on Levitsy and $\mathrm{Way}^{28}$ we denote this as democratic leverage, that 
is, the extent to which a democratic country has bargaining power relative to an autocratic regime. The more leverage the former has, the more vulnerable the latter is to the external pressures for change that come associated with aid in the form of conditionalities.

We argue that democratic leverage has a moderating effect on the relationship between foreign aid and autocratic survival. We expect the effect of aid to shorten the life of an authoritarian regime not when democratic aid is conditional to institutional change, but when the democratic donor has the capability to impose costs on the authoritarian coalition in the case of defection. ${ }^{29}$ The effect of democratic leverage on autocratic duration is a matter of degree: democratic countries, such as the United States, have exerted more leverage than other countries. An important empirical literature details the several ways in which the Agency for International Development, the State Department, the United States Information Agency, the Justice Department, and the National Endowment for Democracy, among others, were effective promoters of democracy during the third wave and its aftermath. ${ }^{30}$

\section{The role of democratic leverage: Four mechanisms}

What are the mechanisms through which democratic leverage moderates the effect of foreign aid on autocratic survival? We identify four potential pathways. First, democratic leverage can alter the effect of aid on autocratic duration by allowing the democratic donor to effectively promote the reactivation of civil society and opposition forces on the ground. ${ }^{31}$ Many case studies illustrate these mechanism in detail. Before the 1984 Salvadoran elections, for example, several of the aforementioned United States' agencies financed campesino organizations and labor unions, gave them legal advice, and offered considerable training on how to run a campaign. Washington also helped create NGOs designed to monitor human right practices and the rule of law. All these endeavors were facilitated by constant political pressure on the military, including a personal meeting of Vice President George H. W. Bush with Salvadoran generals in which he conveyed the importance of these initiatives and expressed that the continuity of military aid depended on their progress. ${ }^{32}$ The result was a formidable strengthening of the civil society that possibly explains the collapse of the authoritarian coalition, the success of subsequent elections, and the stability of the democratic regime. ${ }^{33}$ Washington would have found it difficult to intervene in this way beyond the Western hemisphere.

Second, democratic leverage can contribute to the development of a coherent institutional framework through effective technical assistance and monitoring. Although most of the time aid seems to damage political institutions and autocrats often work their way around such constraints, ${ }^{34}$ there are reasons to believe that aid can enhance effective institutions under 
specific conditions. ${ }^{35}$ This is perhaps the most common storyline describing how foreign assistance helped foster gradual liberalization in East Asia. ${ }^{36}$ Taiwan is a case in point. American anti-authoritarian preferences were always clear, but extensive and steady aid flows became an effective regime promotion tool only when investments in electoral and party institutions took place starting in 1990. Free elections in 1996 and the Kuomintang's surrender of power in 2000, however, were largely a result of concurrent pressures from Beijing, which increased the leverage of the United States visà-vis elites in Taipei eager to secure their alliance. ${ }^{37}$ Nicely illustrating the link between security and democracy that we propose, President Bill Clinton deployed two aircraft carriers to the seas just off Taiwan on March 9, 1996, two weeks before the elections that mark the democratic transition. ${ }^{38}$ Recent qualitative scholarship has noticed that aid directed to strengthen local institutions has been relatively inefficient in autocracies with higher leverage. Historically, Vietnam received five to seven times the institutional assistance South Korea and Taiwan did, but autocracy survived due to low United States levarage. ${ }^{39}$

Third, the existence of leverage over an autocratic recipient can ensure that foreign aid is allocated to development projects. The possibility that local development, in turn, will cause authoritarian collapse, is based on the tenets of modernization theory. Foreign aid could raise citizens' living standards, give way to self-expression values, and strengthen the demands for civil and political liberties. ${ }^{40}$ Researchers have found that poverty does mediate the effect of aid on democracy in certain regions. ${ }^{41}$ In Africa, aid spent in social infrastructure and economic infrastructure usually renders positive socioeconomic results, ${ }^{42}$ which are in turn related to a probability of regime transition. ${ }^{43}$ Moreover, when aid comes from democratic patrons, liberal norms might trickle down to local actors and impose constraints to the autocratic leader. ${ }^{44}$ Yet Dunning ${ }^{45}$ provides strong evidence suggesting that Western conditionalities only produced these type of positive effects after the end of the Cold War, when the leverage of authoritarian leaders was severely damaged by the collapse of the Soviet Union as an alternative donor. He illustrates this mechanism using the case of Benin, where the reforms promoted by Western donors-leading to development in both the economic and then the political realms-were only possible after 1989, when aid flows from Moscow suddenly collapsed and allowed for democratic conditionality to kick in. In his visit to Benin in 1994, Vice President Albert Gore promised a "Marshall Plan," conveying this link between development, democracy, and Western victory against the Soviet Union. Other cases suggest that even within the post-Cold War era, conditionality was more effective in countries more dependent on aid-like Mozambique-when compared to countries that could resort to oil rents or other sources of income-like Angola. ${ }^{46}$ 
Fourth, a democratic donor with very high leverage can disarticulate the authoritarian coalition by simply threatening to withdraw aid. Evidence of this mechanism abounds in Africa and Latin America. In 1978, for example, the United States wanted to secure the integrity of the Dominican elections that, in retrospect, would trigger the Latin American third wave. Ambassador Robert Yost was deployed with the task of securing a transition and filled the country with observers. Elections took place on May 16, and by that evening, knowing exit polls were not favorable, president Joaquín Balaguer sent the military to intervene the vote count. Carter's Secretary of State, Cyrus Vance, immediately sent harsh diplomatic protests, and President Carter publicly called on the Dominican president to "permit a free election or lose aid." ${ }^{47}$ At the time the United States provided 70 percent of all aid to the Dominican Republic, and the equipment and salaries of its armed forces depend almost entirely on American military aid. Given this overwhelming leverage, the collapse of the authoritarian regime was ensured when the head of the Southern Command, General Dennis P. McAuliffe, personally called the chief of the Dominican army to let him know that the American military would support Carter's decision to cut all aid. Historians agree that the threat to withdraw aid was "crucial in dismantling the coup in the making." 48

In sum, democratic leverage can help shorten the life expectancy of autocratic regimes by ensuring that aid is used to reactivate civil society, reforming local institutions, and promoting economic development, or simply by making the threat of aid withdrawal more credible and onerous. One can envision a fifth mechanism illustrated by the cases of Afghanistan and Iraq, by which democratic donors suddenly increase both aid and leverage vis-à-vis a specific country for strategic considerations. These cases of foreign imposed regime change, however, fall outside of our scope, as autocratic breakdown takes place before both increases in leverage and aid. For this same reason these cases should not affect our statistical results in the next section.

\section{Research design}

We examine the relationship between foreign aid and autocratic survival around the world from 1950 through $2010 .{ }^{49}$ We start from the idea that autocratic regimes survive longer when they receive higher levels of foreign aid and explore whether higher donor leverage can significantly decrease the authoritarian prospects of survival.

\section{The model}

To model the duration of time spent in the initial state-autocracy-until its failure, we use a Cox proportional hazard model, which provides 
information about the hazard function: the event rate at time $t$ conditional on survival until time $t$ or later. The hazard rate of the Cox model can be expressed as:

$$
h_{i}(t)=h_{0}(t) \exp \left(\text { Aid } * \text { Democratic Leverage } \beta_{1}+\beta \mathbf{X}\right)
$$

where $h_{0}(t)$ is the baseline function, $\beta_{1}$ is the coefficient of the relationship of our interest, and $\beta \mathbf{X}$ is a vector of independent variables. Since we hypothesize that democratic leverage increases the positive effect of foreign aid on autocratic failure, we expect $\beta_{1}$ to yield a positive coefficient. To correct for problems of time dependence, we estimate all of our models with robust standard errors clustered by recipient and year. Unlike fully parametric models, such as the Weibull or Gompertz models, the Cox proportional model does not specify the baseline hazard rate and therefore does not have an intercept term. Instead, the duration times are parameterized in terms of a set of covariates, represented by the beta coefficients. $^{50}$

\section{Autocratic duration}

When studying the dynamic of autocracies, it is possible to put an emphasis on leaders, spells, or regime duration. Each of these aspects implies theoretically different questions. Because our aim is to account for the impact of foreign aid on how long autocratic regimes last, we use the duration of autocratic regimes as our dependent variable. An autocratic spell is a single and continuous period of authoritarianism in a country. Although this measure is relevant for addressing the causes of democratization, it precludes the possibility of observing multiple and consecutive authoritarian regimes. For instance, although a country may have experienced autocracy in the last 50 years of its history, it is possible that multiple and distinct autocratic regimes have taken place during that 50 -year spell. Thus our main outcome of interest is not the duration of spells, but the duration of autocratic regimes.

Our universe of cases comprises all autocratic regimes recorded by Geddes, Wright, and Frantz (GWF) in their Autocratic Regimes Data Set. According to their definition, a span of years is coded autocratic if any of the following took place: (1) the executive achieved power through undemocratic means, that is, any means besides direct, fair, and competitive elections; (2) the government achieved power through democratic means, but subsequently transformed the rules of the game to limit electoral competition; (3) competitive elections were held to choose the government, but the military prevented the participation of one or more political parties. 


\section{Independent and control variables}

Our two key independent variables are foreign aid and democratic leverage. To capture the effect of foreign aid, we use foreign aid per capita (logged), and as a robustness measure, we also use the total amount of aid (logged). Since the effect of aid might have a delayed effect on recipients' regime, we use a one-year lag of both variables. Although foreign aid as percentage of GDP has also been used in the literature, the denominator in Aid/GDP can introduce spurious variation in the presence of economic shocks and shortterm growth. ${ }^{51}$ Although we prefer and indeed use a per capita specification, analyses with aid as percentage of GDP yield very similar results (Appendix B).

ODA collected by the AidData project records the amount of aid an official donor has committed to give to a recipient country in a specific year. Loans or grants are made on concessional terms by official agencies, multilateral institutions, and individual countries-including non-OECD members-to promote economic development and welfare. Since we are exclusively interested in regime survival, we exclude non-state recipients from the sample. An advantage of AidData is that it provides fine-grained information about the transfer of resources, as it records the amount of aid a country received from all donors in a specific year.

Our second independent variable of interest is the degree of leverage exerted by democratic donors on autocratic regimes. To account for this, we use David Lake's ${ }^{52}$ measure of security hierarchy in the international system, which focuses on United States' influence in the international system. A quintessential case of a democratic donor with political influence around the globe, focusing on the United States allows us to capture the conditional effect of democratic leverage on autocracies. Security hierarchies refer to the extent to which a dominant state, the United States in this case, possesses a relation of authority over specific countries. More concretely, this indicator captures the degree of military and coercive influence exerted by the United States over a particular country, and it is measured by two indicators: (1) the deployment of military forces from the United States on the territory of the subordinate country, and (2) the number of independent alliances possessed by the subordinate state-i.e., the larger the number of independent alliances possessed by a country, the less hierarchical the security relationship between that country and the United States. Both indicators are added together and normalized to one. We expect this measure of hierarchy to convey whether a country is effectively under the sphere of influence of Western democracies and therefore unable to use the support of other authoritarian regimesLevistky and Way's "black knights"-as a source of leverage.

We use a second variable to capture the effect of democratic leverage, namely, the proportion of aid coming from democratic donors in a particular year. While 
the security hierarchy variable refers to the leverage exerted by Washington, we also want to explore whether dependence on democratic donors has a negative effect on the survival of the autocratic recipients. Our hypothesis suggests that foreign aid coming from democratic donors is more likely to have a positive effect on the duration of autocracies. Foreign aid coming from less democratic countries, on the other hand, is expected to help autocracies increase their survival rates. This variable is measured as the proportion of aid received by an autocratic recipient that comes from democratic donors: we expect that larger proportions of democratic aid should have a decreasing effect on autocratic survival. To determine which donors can be considered democratic, we use Polity IV's Polity score, which ranges from -10 to 10 . For ease of interpretation, we recode this variable to a scale from 1 to 21 , where higher scores indicate higher levels of democracy. We code countries as democracies if they score 18 or above. As a robustness check and alternative to Polity's measure, we use Boix, Miller, and Rosato's ${ }^{53}$ dichotomous indicator of democracy. Inspired by Robert Dahl, this dichotomous measure codes a country as democratic if it satisfies conditions for both contestation and participation. Empirical results remain significant and consistent across both measures.

Additionally, we borrow a set of other important control variables from the regime's literature. We use a Cold War dummy to stratify our model. In doing so, one allows each of the strata (e.g., Cold War period, post-Cold War period) to have its own baseline hazard rate while the coefficients are the same across strata. ${ }^{54}$ We do this based on the argument that, given the particular political support provided by the Soviet Union and the United States toward certain regimes, the baseline hazard for autocracies during the Cold War differs from the baseline hazard for autocracies during the postCold War era. ${ }^{55}$ In order to control for the role of past instability on regime duration, we include Past Coup, a one-year lagged dichotomous variable specifying whether a coup took place in a particular year. Past instability should decrease the survival rate of political regimes, including autocracies. Coup data comes from Powell and Thyne. ${ }^{56}$

To control for other salient variables, we include population density from Arthur Banks's Cross-national Time-series data archive. We also control for economic growth, with the expectation that larger growth rates should strengthen the autocrat's power and contribute to longer regime duration. This variable is measured as the annual percentage growth rate of GDP based on constant local currency. In addition, we include a measure of logged per capita GDP, in order to control for a country's wealth. While GDP growth best captures sudden increases or drops in the economic performance, per capita GDP accounts for how rich a country is. Data for GDP come from the Penn World Table. Lastly, because oil-dependent countries are associated with the hindering of democratization, we include one-year lag of oil 
production for each country in number of barrels. We take these data from Ross and Mahdavi. ${ }^{57}$

\section{Empirical results}

What is the impact of foreign aid on the chances of autocratic survival? How does the leverage of democratic donors shape the ultimate impact of foreign aid on the duration of authoritarian regimes? While foreign aid may prolong the life of autocracies, our results suggest that the direction of the relationship changes as the proportion of democratic donors grows larger, on the one hand, and when the United States has higher leverage, on the other.

Before discussing our empirical results, we describe some general patterns found in the data. Figure 1 plots the density function of regime type-as measured by Polity-for both donors and recipients. Because our sample is restricted to autocratic regimes, the vast majority of recipients unsurprisingly have a score below 15. Granted, while some very few recipients show a higher democracy score, this may stem from a conceptual departure from Geddes et al.'s notion of autocracy. More interestingly, however, the plot shows that the vast majority of donors are democratic countries, some few donors are fully autocratic, and almost no donor country has middling levels of democracy-although some might interpret this as due to the lack of transparency in authoritarian aid. $^{58}$

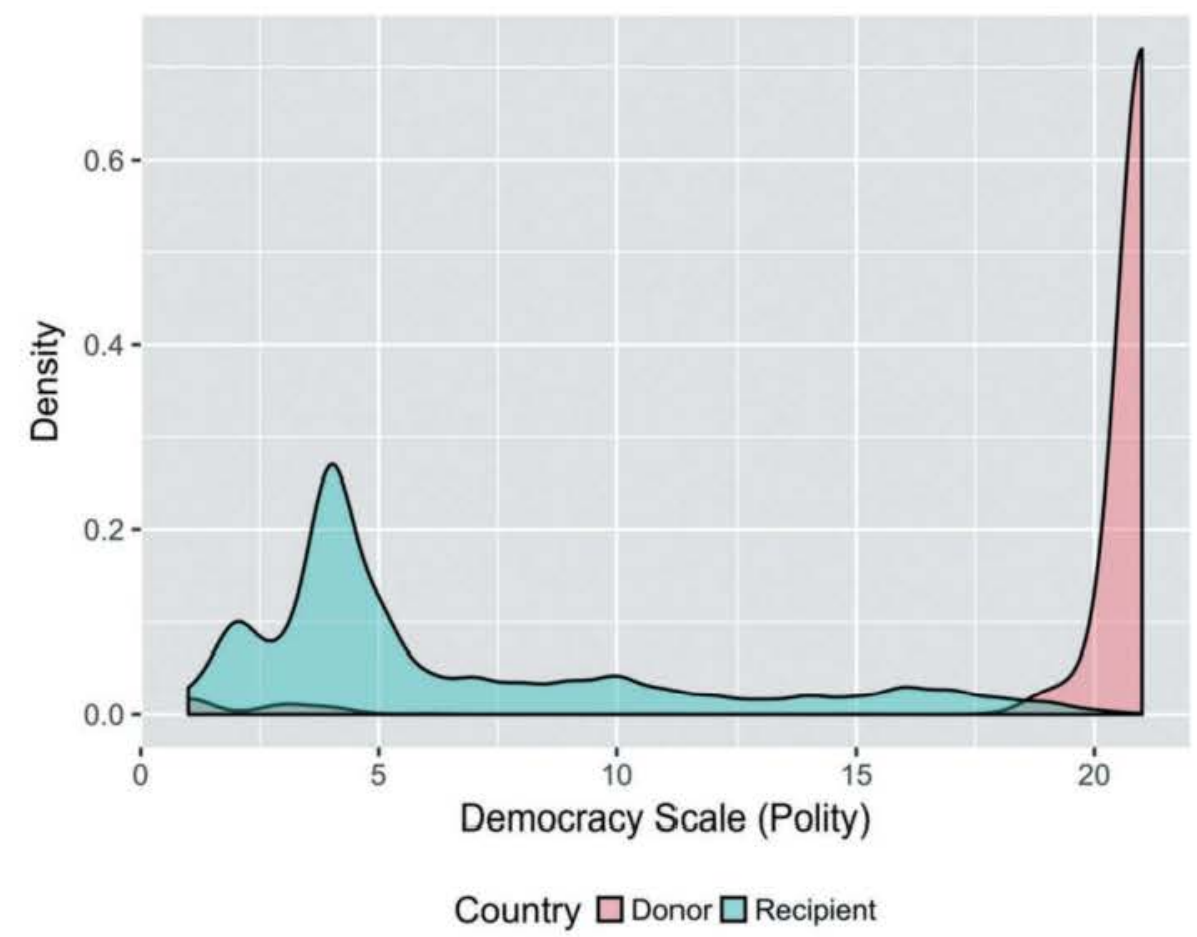

Figure 1. Density function of regime typedonors and recipients. 


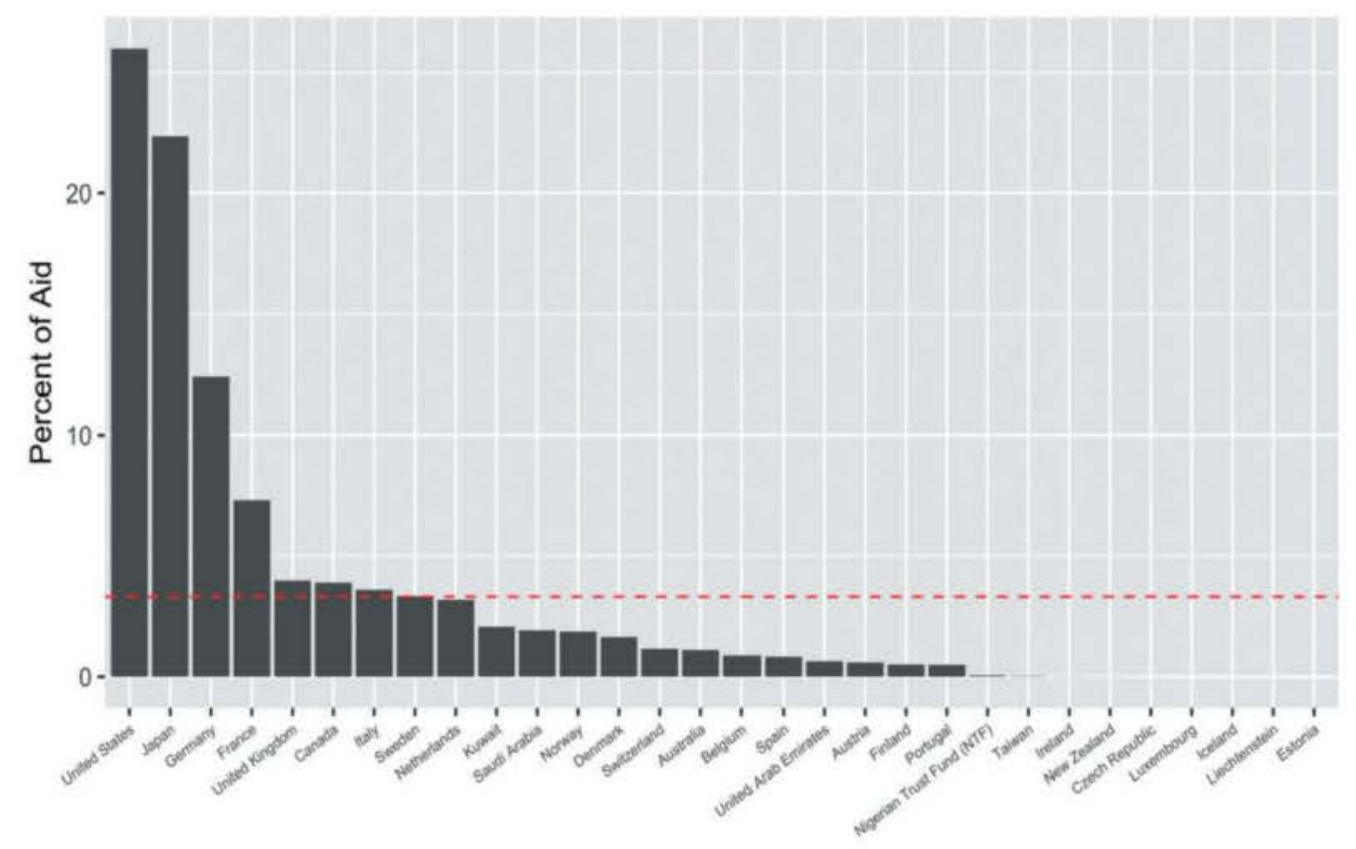

Figure 2. Percent of foreign aid by donor.

Likewise, Figure 2 shows the percentual amount of foreign aid given by each country during the entire timeframe considered in the sample. Only eight out of the 30 donor countries, the data indicate, have contributed above the mean contribution, as denoted by the red dashed line. Not surprisingly, the United States appears as the top donor, followed by Japan, Germany, and France. Furthermore, the difference between the largest and smallest donor is noteworthy: while the United States appears as the largest donor of development assistance with over 25 percent of the total, countries such as Estonia, Iceland, and Luxemburg have not made substantial contributions relative to other countries.

We now turn to the empirical results of our quantitative analysis. We show our results in Table 1 from three different models. For all three models, as shown in Appendix A, we conduct proportionality tests and obtain $p$ values greater than 0.05 for each individual variable as well as for the global model. This suggests that our estimations do not violate the proportionality assumption and that our inferences are indeed correct. In the first model, we estimate whether foreign aid, by itself, has any impact on autocratic duration; in Model 2, we include an interaction term between the per capita aid in a country and the proportion of aid coming from democratic donors. This second term is important, as it specifies the extent to which a recipient's aid allocation is dependent on democratic donors in a given year. In the third model, we estimate an interaction effect between foreign aid and the specific leverage of the United States vis-à-vis the autocratic regime. All of our models control for coup events, population density, GDP per capita, economic growth, and oil production. 
Table 1. Cox proportional hazard models.

\begin{tabular}{lcll}
\hline & Model 1 & Model 2 & Model 3 \\
\hline Aid pc & -0.008 & $-0.232^{* *}$ & $-0.002^{* *}$ \\
Aid pc $\times$ democratic aid & $(0.014)$ & $(0.073)$ & $(0.001)$ \\
Aid pc $\times$ US leverage & & $0.221^{*}$ & \\
Democratic aid & & $(0.104)$ & $0.106^{* * *}$ \\
& & & $(0.031)$ \\
US leverage & & 0.770 & \\
& & $(0.585)$ & $1.335^{* * *}$ \\
Coup & & & $(0.208)$ \\
& & & $1.569^{* * *}$ \\
Oil & $1.57^{* * *}$ & $1.582^{* * *}$ & $(0.217)$ \\
& $(0.222)$ & $(0.234)$ & $0.006^{* *}$ \\
Growth & -0.009 & -0.007 & $(0.012)$ \\
& $(0.011)$ & $(0.011)$ & $-2.623^{* *}$ \\
GDP pc & $-3.350^{* * *}$ & $-4.224^{* * *}$ & $(0.820)$ \\
& $(0.759)$ & $(0.811)$ & $-0.530^{* * *}$ \\
Population D & $-0.354^{* * *}$ & $-0.351^{* * *}$ & $(0.132)$ \\
AIC & $(0.106)$ & $(0.103)$ & -0.000 \\
$R^{2}$ & -0.000 & -0.000 & $(0.000)$ \\
Max. R & $(0.000)$ & $(0.000)$ & 2031.80 \\
Num. events & 2291.27 & 2280.19 & 0.04 \\
Num. obs. & 0.03 & 0.03 & 0.53 \\
PH Test & 0.51 & 0.51 & 154 \\
\hline & 168 & 168 & 2817 \\
\hline & 3290 & 3290 & 0.06 \\
\hline
\end{tabular}

${ }^{* * *} p<0.01,{ }^{* *} p<0.05,{ }^{*} p<0.1$ Robust standard errors clustered by recipient and year. Note: Aid per capita is the log average of foreign aid per each inhabitant. Democratic aid refers the proportion of aid coming from democratic donors in a given year. US leverage is a continuous measure capturing the extent to which a country is dependent on the United States. The three variables have a one-year lag.

Results from Model 1 suggest that higher levels of foreign aid decrease the hazard rate of autocratic failure. Although the coefficient is not statistically significant, the negative relationship is consistent with some of the findings in the literature, according to which unearned income-such as oil or foreign aid-has deleterious consequences for development and democratization. ${ }^{59}$ The remaining models, however, suggest that this is only partially true. Instead, we find statistical evidence to contend that democratic leverage, in particular that exerted by the United States, plays an important role in explaining the heterogeneous effects of foreign aid on autocratic survival.

In Model 2, we explore how autocratic duration is affected by the interaction between per capita ODA and the proportion of aid coming from democratic countries. The positive hazard rate of the interaction term indicates that foreign aid has a negative effect on autocratic survival as the proportion of aid coming from democratic donors increases. To better understand the effect of foreign aid conditional on different levels of democratic aid, we simulate the marginal effects and plot them in the left-hand panel of Figure 3. Some elements are worth noting: first, the curve's shape in 

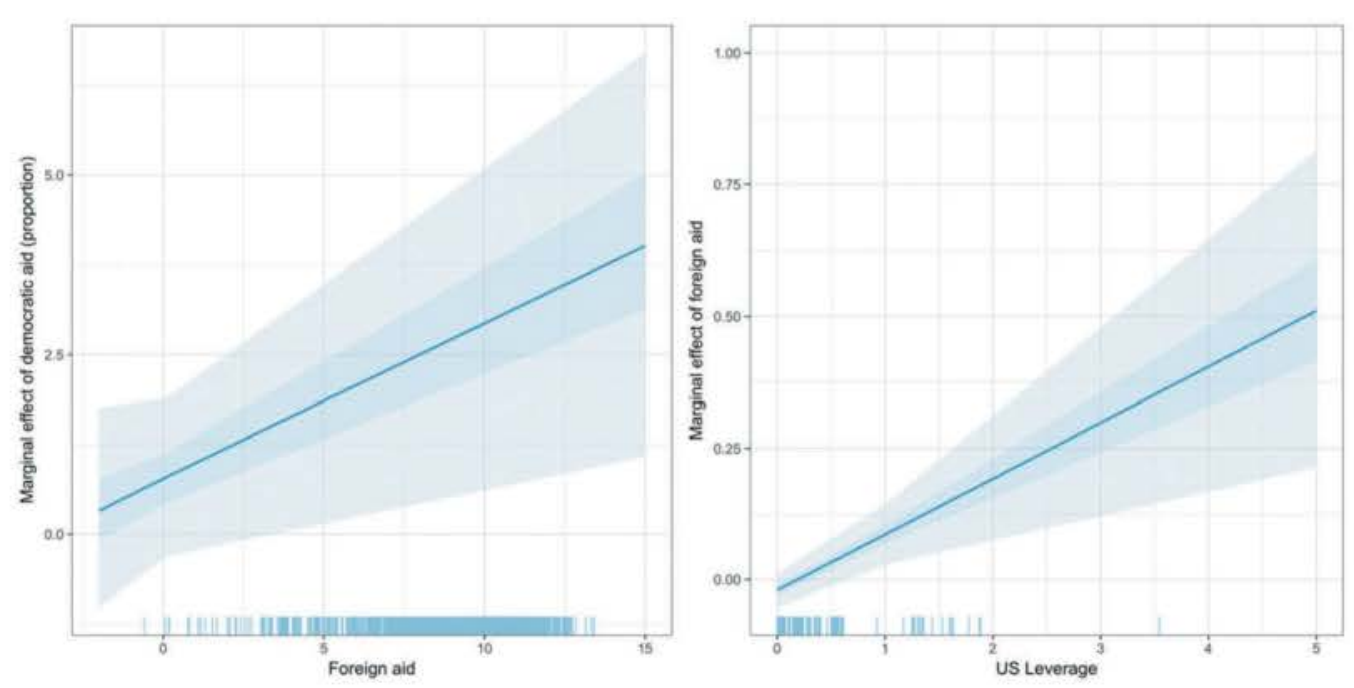

Figure 3. Marginal effects-models 2 and 3.

Figure 3 is consistent with the hypothesis specified for Model 2, namely that foreign aid is likely to shorten the longevity of autocracies as the proportion of democratic aid increases. Indeed, when looking at the marginal effects of democratic aid conditional on levels of aid per capita, it is possible to see that the magnitude of democratic aid is positive and significant at almost all levels of per capita foreign aid. Importantly, in autocracies receiving aid from democratic donors, larger amounts of aid are likely to have larger impacts on their regimes than smaller amounts of aid. Larger amounts of aid are probably more effective because they are able to more rapidly transform autocracies' political conditions. Not coincidentally, as suggested by Figure 2, the largest donors are also those countries with the most exemplary democracies. In fact, while our argument suggests that democratic donors' leverage is likely to affect autocratic survival, we argue that it is a matter of degree: the greater the leverage a democratic country has over an autocracy, the more vulnerable the autocratic recipient is.

We further investigate the moderating effect of democratic donors by focusing on the impact of the United States, a quintessential case of democratic leverage in the international system. To do so, Model 3 estimates an interaction term between foreign aid and United States leverage-as measured by Lake's security hierarchy. The results suggest that increasing levels of democratic leverage vis-à-vis an autocratic regime moderates the impact of foreign aid on autocracies' longevity. The right-hand panel in Figure 3 plots the marginal effect of foreign aid on autocratic failure at different levels of United States leverage. As the plot suggests, foreign aid has an increasing positive effect on autocratic survival as this leverage increases.

More specifically, in cases where the United States exerts no leverage over an autocratic recipient, an additional unit of foreign aid has a negative effect 
on autocratic failure. As democratic leverage increases, however, foreign aid begins to have a positive impact on the failure of autocracies. For instance, in cases where the United States has a strong leverage (i.e., leverage $=5$ ), an additional unit of foreign aid increases the risk of autocratic failure by over 50 percent. While there are few cases where democracies had such a high influence, the figure suggests that even at lower values of United States leverage, its moderating effect on autocratic survival is still significant: in autocracies with a United States leverage of around 1, an additional unit of foreign aid yields an estimated increase of around 10 percent. Since almost 23 percent of the cases of our sample have a level of United States leverage between .5 and 1.5 , this is a meaningful result.

In addition to this, we plot the surface response of the interaction between foreign aid and United States leverage in Figure 4. Surface plots are useful tools to visualize the interaction effect of two continuous variables (represented on the two horizontal axes) on a particular outcome (represented on the vertical axis), where the direction of the arrows indicates larger values of the variable. Lighter shades are areas of higher joint density between the interacting variables. Overall, the figure suggests that autocracies' probability

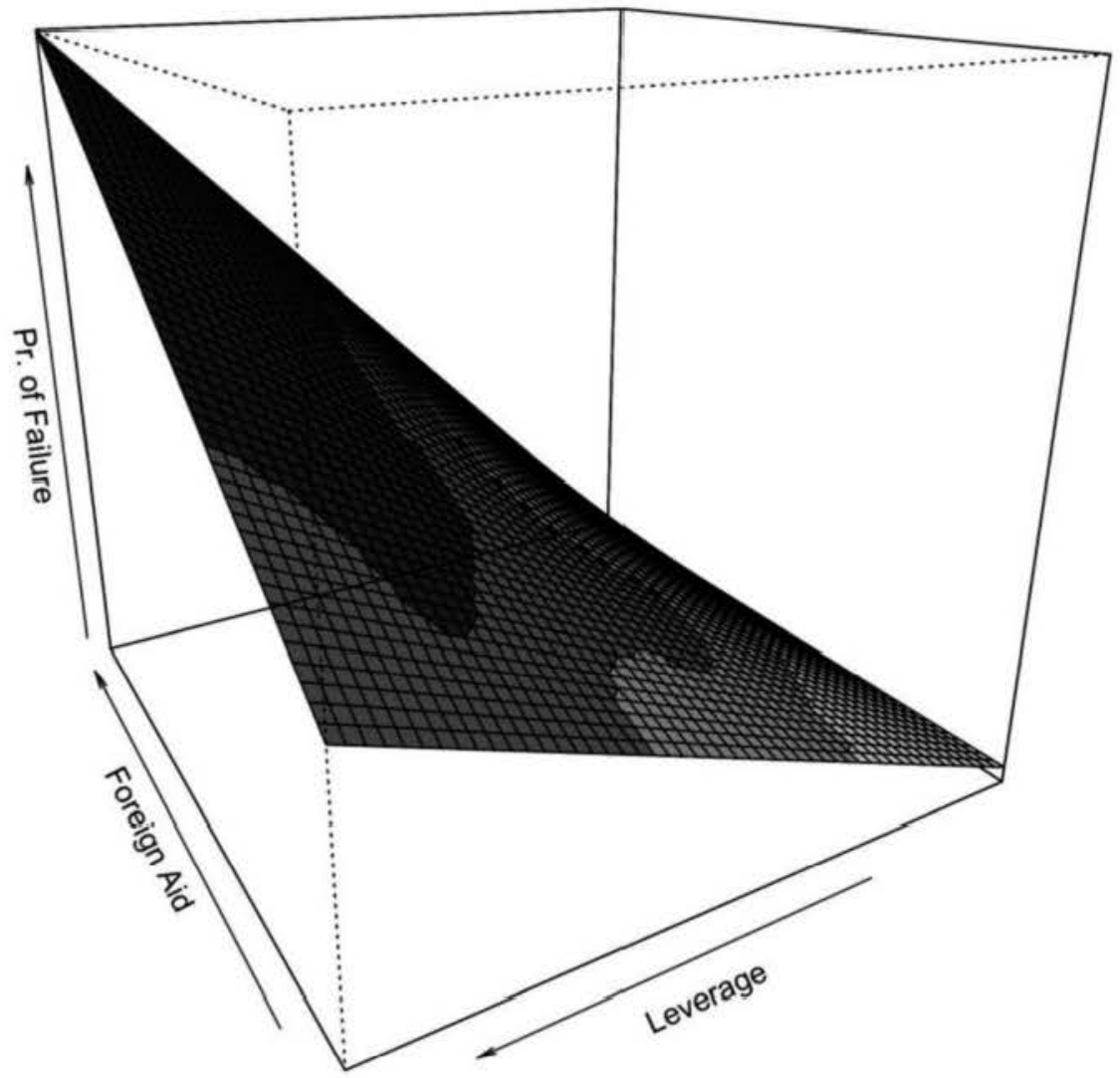

Figure 4. Interaction effect of US leverage and aid on autocratic survival. 
of failure is highest when Washington exerts an important leverage over them: in the upper left area of the plot, where larger values of foreign aid and United States leverage converge, the probability of autocratic leverage is highest. In support for our hypothesis, the plot corroborates that foreign aid does not automatically become an important "survival resource" for autocrats, so long as the United States exerts an important leverage on the autocratic regime. When observed more carefully, the plot also shows that under a strong United States leverage, the probability of autocratic failure increases when foreign aid is higher than when it is lower. In sum, while foreign aid may have a perverse effect in prolonging the life of autocracies, this effect is likely to be altered when the country is strongly influenced by a powerful democracy.

Our results do not necessarily contradict the fact that foreign aid can prolong the life of autocratic regimes. After all, autocrats are aware that windfall resources provide political power and prevent the population from engaging in active accountability. ${ }^{60}$ However, we do provide a more nuanced explanation to the state of the literature. In particular, our results indicate that strong democratic leverage, such as that exerted by the United States, is a key factor that accounts for the diverging results.

\section{Concluding remarks}

We have attempted to answer a specific question: Does foreign aid allocation in autocratic regimes increase the probability of regime survival? We find statistical evidence suggesting that autocratic regimes may indeed benefit from external income. However, we find that this is conditional on the leverage exerted by the democratic donors, and in the presence of strong democratic leverage, the life expectancy of autocracies declines sharply.

Furthermore, our consideration of democratic leverage seems to explain the diverging conclusions of the previous literature on the effects of foreign aid. Those who came to promising conclusions linking aid with democratization had been focusing on aid from democratic donors in time spans and regions where they had great leverage vis-à-vis the authoritarian regime. Conversely, those who found aid to have a pro-authoritarian effect considered large time periods and more encompassing categories of aid, therefore diluting the effect of democratic leverage variable.

However useful to make sense of previous findings and broad mechanisms, this article leaves many questions still open. While we have explored the impact of aid on authoritarian survival, this is not necessarily equivalent to explore its impact on democratization or levels of democracy. Also, while we find that the leverage democracies derive from the security hierarchy is relevant to explain the effects of aid, this is not necessarily the case for other types of economic or social sources of leverage. In sum, while this article has 
found in the concept of democratic leverage a way to connect the skeptics and optimists of foreign aid, it has opened several avenues of research that should be pursued further.

Despite these many remaining blind spots, this article also results in relevant policy recommendations. Alleging the futility of democratic promotion, the Trump administration appears to have abandoned a longstanding policy of the United States consisting in countering authoritarianism through the use of aid. Impactful initiatives of the State Department and foundations such as the National Endowment for Democracy have been jeopardized due to this misunderstanding. Our findings suggest aid can make a difference if deployed under the proper strategic conditions. Whether these conditions are present or not will become an issue of increasing concern in a world where democratic leverage is in decline.

\section{Acknowledgements}

We wish to thank Angie Bautista-Chavez, Chonghyun Choi, Hernán Flom, Gary Goertz, Gary Hollibaugh, Scott Mainwaring, and participants at the Notre Dame Comparative Politics Workshop and the 2016 meeting of the Midwest Political Science Association. We are also thankful with two anonymous reviewers and the editor for their useful comments on different components of the manuscript.

\section{Disclosure statement}

No potential conflict of interest was reported by the authors.

\section{ORCID}

Camilo Nieto-Matiz (C) http://orcid.org/0000-0002-1917-003X

Luis L. Schenoni (1) http://orcid.org/0000-0001-6770-2136

\section{Notes}

1. Thad Dunning, "Conditioning the Effects of Aid: Cold War Politics, Donor Credibility, and Democracy in Africa," International Organization 58 (2004): 409-23; Steven E. Finkel, Aníbal Pérez-Liñán, and Mitchell Seligson, "The Effects of US Foreign Assistance on Democracy Building, 1990-2003," World Politics 59 (2007): 404-39; Arthur A. Goldsmith, "Foreign Aid and Statehood in Africa," International Organization 55, no. 1 (2001): 123-48, https://doi.org/10.1162/002081801551432; Sarantis Kalyvitis and Irene Vlachaki, "Democratic Aid and the Democratization of Recipients," Contemporary Economic Policy 28, no. 2 (2010): 188-218, https://doi.org/10.1111/j.1465-7287.2009. 00154.x; James M. Scott and Carie A. Steele, "Sponsoring Democracy: The United States and Democracy Aid to the Developing World, 1988-20011," International Studies Quarterly 55, no. 1 (2011): 47-69, https://doi.org/10.1111/j.1468-2478.2010.00635.x. 
2. Bruce Bueno de Mesquita and Alastair Smith, "Leader Survival, Revolutions, and the Nature of Government Finance," American Journal of Political Science 54, no. 4 (2010): 936-50, https://doi.org/10.1111/j.1540-5907.2010.00463.x; Simeon Djankov, Jose G. Montalvo, and Marta Reynal-Querol, "The Curse of Aid," Journal of Economic Growth 13, no. 3 (2008): 169-94, https://doi.org/10.1007/s10887-008-9032-8; Matthew D. Fails and Marc C. DuBuis, "Resources, Rent Diversification, and the Collapse of Autocratic Regimes," Political Research Quarterly 68, no. 4 (2015): 703-15, https://doi. org/10.1177/1065912915601895; Amanda A. Licht, "Coming into Money: The Impact of Foreign Aid on Leader Survival," Journal of Conflict Resolution 54, no. 1 (2010): 58-87, https://doi.org/10.1177/0022002709351104; Kevin M. Morrison, "Oil, Nontax Revenue, and the Redistributional Foundations of Regime Stability," International Organization 63, no. 1 (2009): 107-38, https://doi.org/10.1017/S0020818309090043; Alastair Smith, "The Perils of Unearned Income," Journal of Politics 70, no. 3 (2008): 780-93, https://doi.org/ 10.1017/S0022381608080754; Joseph Wright and Matthew Winters, "The Politics of Effective Foreign Aid," Annual Review of Political Science 13, no. 1 (2010): 61-80, https://doi.org/10.1146/annurev.polisci.032708.143524.

3. Nabamita Dutta, Peter T. Leeson, and Claudia R. Williamson, "The Amplification Effect: Foreign Aid's Impact on Political Institutions," Kyklos 66, no. 2 (2013): 208-28, https://doi.org/10.1111/kykl.12018; Daniel Yuichi Kono and Gabriella R. Montinola, "Foreign Aid, Time Horizons, and Trade Policy," Comparative Political Studies 48, no. 6 (2015): 788-819, https://doi.org/10.1177/0010414014556048.

4. Stephen Knack, "Does Foreign Aid Promote Democracy?" International Studies Quarterly 48 (2004): 251-66.

5. Julia Bader, China's Foreign Relations and the Survival of Autocracies (London: Routledge, 2014).

6. Lawrence Whitehead, "International Aspects of Democratization," in Transitions from Authoritarian Rule: Comparative Perspectives, ed. Guillermo O'Donnell, Philippe C. Schmitter, and Lawrence Whitehead (Baltimore: JHU Press, 1986), 3-46.

7. Luis L. Schenoni and Scott Mainwaring, "US Hegemony and Regime Change in Latin America," Democratization (September 12, 2018): 1-19, https://doi.org/10.1080/ 13510347.2018.1516754.

8. Finkel, Pérez-Liñán, and Seligson, "The Effects of US Foreign Assistance on Democracy Building, 1990-2003."

9. Dunning, "Conditioning the Effects of Aid: Cold War Politics, Donor Credibility, and Democracy in Africa."

10. Finkel, Pérez-Liñán, and Seligson, "The Effects of US Foreign Assistance on Democracy Building, 1990-2003," 436.

11. Scott and Steele, "Sponsoring Democracy."

12. Kalyvitis and Vlachaki, "Democratic Aid and the Democratization of Recipients."

13. Knack, "Does Foreign Aid Promote Democracy?"

14. Sheila Carapico, "Foreign Aid for Promoting Democracy in the Arab World," Middle East Journal 56, no. 3 (2002): 379-95.

15. Kalyvitis and Vlachaki, "Democratic Aid and the Democratization of Recipients."

16. Agnes Cornell, "Does Regime Type Matter for the Impact of Democracy Aid on Democracy?," Democratization 20, no. 4 (2013): 642-67, https://doi.org/10.1080/ 13510347.2012.659021; Eric Neumayer, The Pattern of Aid Giving: The Impact of Good Governance on Development Assistance (London: Routledge, 2003).

17. Bueno de Mesquita and Smith, "A Political Economy of Aid"; Djankov, Montalvo, and Reynal-Querol, "The Curse of Aid"; Fails and DuBuis, "Resources, Rent Diversification, and the Collapse of Autocratic Regimes"; Licht, "Coming into Money"; Morrison, "Oil, 
Nontax Revenue, and the Redistributional Foundations of Regime Stability"; Smith, "The Perils of Unearned Income"; Wright and Winters, "The Politics of Effective Foreign Aid."

18. "Coercive capacity is central to competitive authoritarian stability. The greater a government's capacity to either prevent or crack down on opposition protest, the greater are its prospects for survival" (Levitsky and Way, 2006: 57).

19. Kono and Montinola (2009) agree with the general intuition (among skeptics) that aid promotes political survival of despots but think that this effect is also present in democracies. In autocracies, leaders can stockpile aid-based resources for the future and use it only for instances of negative shocks. In democracies, however, since leaders must spend those resources as they become available, they may lack financial sources for countering negative shocks. Thus aid helps both, but it helps autocrats more in the long run.

20. Djankov, Montalvo, and Reynal-Querol, "The Curse of Aid"; Fails and DuBuis, "Resources, Rent Diversification, and the Collapse of Autocratic Regimes"; Licht, "Coming into Money."

21. See Finkel, Pérez-Liñán, and Seligson, "The Effects of US Foreign Assistance on Democracy Building, 1990-2003"; Kalyvitis and Vlachaki, "Democratic Aid and the Democratization of Recipients"; Scott and Steele, "Sponsoring Democracy."

22. Rachel M. Gisselquist, "Aid and Institution-building in Fragile States: What Do We Know? What Can Comparative Analysis Add?" Annals of the American Academy of Political and Social Science 656, no. 1 (2014): 6-21, https://doi.org/10.1177/ 0002716214546991; Mark Robinson, "Aid, Democracy and Political Conditionality in Sub-Saharan Africa," European Journal of Development Research 5, no. 1 (1993): 85-99, https://doi.org/10.1080/09578819308426580; Schenoni and Mainwaring, "US Hegemony and Regime Change in Latin America."

23. Kono and Montinola, "Foreign Aid, Time Horizons, and Trade Policy"; Morrison, "Oil, Nontax Revenue, and the Redistributional Foundations of Regime Stability"; Wright and Winters, "The Politics of Effective Foreign Aid."

24. Alberto Alesina and Beatrice Weder, "Do Corrupt Governments Receive Less Foreign Aid?," American Economic Review 92, no. 4 (2002): 1126-37, https://doi.org/10.1257/ 00028280260344669; Barbara Geddes, "What Do We Know about Democratization after Twenty Years?," Annual Review of Political Science 2, no. 1 (1999): 115-44, https://doi.org/10.1146/annurev.polisci.2.1.115; Michael L. Ross, "How Do Natural Resources Influence Civil War? Evidence from Thirteen Cases," International Organization 58, no. 1 (2004): 35-67, https://doi.org/10.1017/S002081830458102X.

25. Fails and DuBuis, "Resources, Rent Diversification, and the Collapse of Autocratic Regimes"; Knack, "Does Foreign Aid Promote Democracy?"; Kono and Montinola, "Foreign Aid, Time Horizons, and Trade Policy"; Licht, "Coming into Money."

26. Ross, "How Do Natural Resources Influence Civil War?"

27. Miguel Angel Centeno, Blood and Debt: War and the Nation-State in Latin America (Penn State University Press, 2005), http://www.psupress.org/books/titles/978-0-27102165-2.html.

28. Levitsky and Way, Competitive Authoritarianism.

29. See Daniel W. Drezner, "The Hidden Hand of Economic Coercion," International Organization 57, no. 3 (2003): 643-59, https://doi.org/10.1017/S0020818303573052; Lake, "Escape from the State of Nature"; Levitsky and Way, Competitive Authoritarianism.

30. Thomas Carothers, "Resurgence of United States Political Development Assistance to Latin America in the 1980s," in The International Dimension of Democratization, ed. 
Lawrence Whitehead (New York: Oxford University Press, 1996), http://www. oxfordscholarship.com/view/10.1093/0199243751.001.0001/acprof-9780199243754-

chapter-5; Steven E. Hendrix, "USAID Promoting Democracy and the Rule of Law in Latin America and the Caribbean," Southwestern Journal of Law and Trade in the Americas 9 (2003 2002): 277; Michael J. Kryzanek, US-Latin American Relations, 4th edition (Westport, CT: Praeger, 2008).

31. Marina Ottaway and Thomas Carothers, Funding Virtue: Civil Society Aid and Democracy Promotion (Carnegie Endowment for International Peace, 2000).

32. Luis Schenoni and Scott Mainwaring, "US Hegemony and Regime Change in Latin America," online appendix 3.

33. Scott Mainwaring and Aníbal Pérez-Liñán, Democracies and Dictatorships in Latin America: Emergence, Survival, and Fall (New York: Cambridge University Press, 2013).

34. Andrew T. Young and Kathleen M. Sheehan, "Foreign Aid, Institutional Quality, and Growth," European Journal of Political Economy 36 (2014): 195-208, https://doi.org/10. 1016/j.ejpoleco.2014.08.003.

35. Steven Finkel E., Aníbal Pérez-Liñán, and Mitchell Seligson, "The Effects of US Foreign Assistance on Democracy Building, 1990-2003," World Politics 59 (2007): 404-39; Burcu Savun and Daniel C. Tirone, "Foreign Aid, Democratization, and Civil Conflict: How Does Democracy Aid Affect Civil Conflict?," American Journal of Political Science 55, no. 2 (2011): 233-46, https://doi.org/10.1111/j.1540-5907.2010.00501.x.

36. Robert Wade and Princeton University, Governing the Market: Economic Theory and the Role of Government in East Asian Industrialization (Princeton, NJ: Princeton University Press, 2004).

37. John W. Garver, Face Off: China, the United States, and Taiwan's Democratization (Seattle: University of Washington Press, 1997).

38. John Dumbrell, Clinton's Foreign Policy: Between the Bushes, 1992-2000 (London: Routledge, 2009), http://www.routledge.com/books/details/9780415359849/.

39. Kevin Gray, "US Aid and Uneven Development in East Asia," Annals of the American Academy of Political and Social Science 656, no. 1 (2014): 41-58, https://doi.org/10. $1177 / 0002716214543899$.

40. Ronald Inglehart and Christian Welzel, Modernization, Cultural Change, and Democracy: The Human Development Sequence (New York: Cambridge University Press, 2005); Seymour Martin Lipset, Political Man: The Social Bases of Politics (New York: Doubleday Anchor, 1963).

41. B. Mak Arvin and Francisco Barillas, "Foreign Aid, Poverty Reduction, and Democracy," Applied Economics 34, no. 17 (2002): 2151-56, https://doi.org/10.1080/ 00036840210136718.

42. Simplice A. Asongu and Jacinta C. Nwachukwu, "Foreign Aid and Inclusive Development: Updated Evidence from Africa, 2005-2012," Social Science Quarterly 98, no. 1 (2017): 282-98, https://doi.org/10.1111/ssqu. 12275.

43. Deborah A. Bräutigam and Stephen Knack, "Foreign Aid, Institutions, and Governance in Sub-Saharan Africa," Economic Development and Cultural Change 52, no. 2 (2004): 255-85, https://doi.org/10.1086/380592.

44. Daniel Ritter, The Iron Cage of Liberalism: International Politics and Unarmed Revolutions in the Middle East and North Africa (New York: Oxford University Press, 2015).

45. Dunning, "Conditioning the Effects of Aid: Cold War Politics, Donor Credibility, and Democracy in Africa."

46. Helena Pérez Niño and Philippe Le Billon, "Foreign Aid, Resource Rents, and State Fragility in Mozambique and Angola," Annals of the American Academy of Political and Social Science 656, no. 1 (2014): 79-96, https://doi.org/10.1177/0002716214544458. 
47. Rober Pastor, Exiting the Whirlpool, 2nd ed. (Boulder: Perseus, 2001).

48. Jonathan Hartlyn, The Struggle for Democratic Politics in the Dominican Republic (Chapel Hill: University of North Carolina Press, 1998). See also G. Pope Atkins, Latin America and the Caribbean in the International System, 4th ed. (Boulder: Perseus, 1999).

49. While the GWF data covers all autocratic regimes from 1945 to 2012, our analysis covers only a subset of this due to missing data in some of our key independent variables.

50. Janet M. Box-Steffensmeier and Bradford S. Jones, Event History Modeling: A Guide for Social Scientists (Cambridge: Cambridge University Press, 2004).

51. Abel Escribà-Folch and Joseph Wright, Foreign Pressure and the Politics of Autocratic Survival (Oxford: Oxford University Press, 2015).

52. Lake, "Escape from the State of Nature."

53. Carles Boix, Michael Miller, and Sebastian Rosato, "A Complete Data Set of Political Regimes, 1800-2007," Comparative Political Studies 46, no. 12 (2013): 1523-54, https:// doi.org/10.1177/0010414012463905.

54. Box-Steffensmeier and Jones, Event History Modeling.

55. Dunning, "Conditioning the Effects of Aid: Cold War Politics, Donor Credibility, and Democracy in Africa."

56. Powell and Thyne, "Global Instances of Coups from 1950 to 2010."

57. Michael Ross and Paasha Mahdavi, "Oil and Gas Data, 1932-2014," 2015, https://doi.org/10. 7910/DVN/ZTPW0Y, Harvard Dataverse, V2. A more appropriate measure would have been oil rents, namely, the percentage of rents coming from oil exports with respect to the GDP. Unfortunately, however, the most complete source goes back only to 1960 .

58. Bader, China's Foreign Relations and the Survival of Autocracies.

59. Smith, "The Perils of Unearned Income."

60. Laura Paler, "Keeping the Public Purse: An Experiment in Windfalls, Taxes, and the Incentives to Restrain Government," American Political Science Review 107, no. 4 (2013): 706-25.

\section{Appendix A. Proportional hazard assumption test}

Table A1. Model 1 from main text.

\begin{tabular}{lrrc}
\hline & \multicolumn{1}{c}{ rho } & chisq & $\mathrm{p}$ \\
\hline Aid per capita & 0.31 & 8.34 & 0.00 \\
Coup & -0.07 & 1.07 & 0.30 \\
Oil & -0.05 & 0.40 & 0.53 \\
Growth & 0.02 & 0.17 & 0.68 \\
Population dens & 0.10 & 0.45 & 0.50 \\
GDP pc & 0.02 & 0.03 & 0.86 \\
GLOBAL & & 11.00 & 0.09 \\
\hline
\end{tabular}

Table A2. Model 2 from main text.

\begin{tabular}{lrrc}
\hline & rho & chisq & $\mathrm{p}$ \\
\hline Aid per capita & 0.04 & 0.22 & 0.64 \\
Democratic aid & 0.02 & 0.12 & 0.73 \\
Coup & -0.08 & 1.40 & 0.24 \\
Oil & -0.06 & 0.49 & 0.49 \\
Growth & -0.01 & 0.05 & 0.82 \\
Population dens & 0.05 & 0.19 & 0.66 \\
GDP pC & 0.03 & 0.11 & 0.74 \\
Aid $\times$ Democr. aid & -0.01 & 0.01 & 0.92 \\
GLOBAL & & 11.75 & 0.16 \\
\hline
\end{tabular}


Table A3. Model 3 from main text.

\begin{tabular}{lrrc}
\hline & rho & chisq & $\mathrm{p}$ \\
\hline Aid per capita & 0.24 & 5.41 & 0.02 \\
US leverage & -0.03 & 0.03 & 0.86 \\
Coup & -0.04 & 0.26 & 0.61 \\
Oil & 0.00 & 0.00 & 0.95 \\
Growth & 0.09 & 3.17 & 0.08 \\
Population dens & 0.19 & 1.95 & 0.16 \\
GDP pc & -0.02 & 0.03 & 0.87 \\
Aid $\times$ US leverage & 0.12 & 0.99 & 0.32 \\
GLOBAL & & 14.77 & 0.06 \\
\hline
\end{tabular}

\section{Appendix B. Alternative measures of aid}

Table B1. Total aid: Cox proportional models.

\begin{tabular}{lccc}
\hline & Model 1 & Model 2 & Model 3 \\
\hline Total aid & -0.00 & $-0.13^{* *}$ & -0.01 \\
& $(0.01)$ & $(0.04)$ & $(0.01)$ \\
Total aid $\times$ democratic aid & & 0.14 & \\
& & $(0.08)$ & $0.06^{* *}$ \\
Total aid $\times$ US leverage & & & $(0.02)$ \\
& & & \\
Democratic aid & & 0.31 & $1.19^{* * *}$ \\
& & $(1.06)$ & $(0.22)$ \\
US leverage & & & $1.57^{* * *}$ \\
& & & $(0.22)$ \\
Coup & $1.56^{* * *}$ & $1.58^{* * *}$ & 0.01 \\
& $(0.22)$ & $(0.22)$ & $(0.01)$ \\
Oil & -0.01 & -0.01 & $-2.65^{* * *}$ \\
& $(0.01)$ & $(0.01)$ & $(0.81)$ \\
Growth & $-3.37^{* * *}$ & $-4.28^{* * *}$ & -0.00 \\
& $(0.75)$ & $(0.81)$ & $(0.00)$ \\
Population & -0.00 & -0.00 & $-0.40^{* * *}$ \\
& $(0.00)$ & $(0.00)$ & $(0.09)$ \\
GDP pc & $-0.27^{* * *}$ & $-0.26^{* *}$ & 2046.86 \\
& $(0.08)$ & $(0.08)$ & 0.04 \\
AIC & 2305.63 & 2294.72 & 0.53 \\
$R^{2}$ & 0.03 & 0.03 & 155 \\
Max. R & 0.51 & 0.51 & 2822 \\
Num. events & 169 & 169 & 1769 \\
Num. obs. & 3295 & 3295 & 0.03 \\
Missing & 1296 & 1296 & \\
PH test & 0.05 & 0.10 & \\
\hline
\end{tabular}

${ }^{* * *} p<0.01,{ }^{* *} p<0.05,{ }^{*} p<0.1$.

Note: Total aid is the log of a country's foreign aid. Democratic aid refers the proportion of aid coming from democratic donors in a given year. US leverage is a continuous measure capturing the extent to which a country is dependent on the United States. The three variables have a one-year lag. 
Table B2. Aid as percentage of GDP: Cox proportional models.

\begin{tabular}{|c|c|c|c|}
\hline & Model 1 & Model 2 & Model 3 \\
\hline Aid/GDP & $\begin{array}{c}-0.00 \\
(0.00)\end{array}$ & $\begin{array}{c}-0.00 \\
(0.00)\end{array}$ & $\begin{array}{c}-0.00 \\
(0.00)\end{array}$ \\
\hline Aid/GDP $\times$ democratic aid & & $\begin{array}{c}0.00 \\
(0.00)\end{array}$ & \\
\hline Aid/GDP $\times$ US leverage & & & $\begin{array}{l}0.00^{* * *} \\
(0.00)\end{array}$ \\
\hline Democratic aid & & $\begin{array}{c}0.30 \\
(0.18)\end{array}$ & \\
\hline US leverage & & & $\begin{array}{l}1.17^{* * *} \\
(0.23)\end{array}$ \\
\hline Coup & $\begin{array}{l}1.56^{* * *} \\
(0.22)\end{array}$ & $\begin{array}{l}1.58^{* * *} \\
(0.22) \\
1.61^{* * * *} \\
(0.22)\end{array}$ & \\
\hline Oil & $\begin{array}{c}-0.01 \\
(0.01)\end{array}$ & $\begin{array}{c}-0.01 \\
(0.01)\end{array}$ & $\begin{array}{c}0.01 \\
(0.01)\end{array}$ \\
\hline Growth & $\begin{array}{l}-3.32^{* * *} \\
(0.75)\end{array}$ & $\begin{array}{c}-3.45^{* * *} \\
(0.75)\end{array}$ & $\begin{array}{l}-2.65^{* * *} \\
(0.81)\end{array}$ \\
\hline Population & $\begin{array}{c}-0.00 \\
(0.00)\end{array}$ & $\begin{array}{c}-0.00 \\
(0.00)\end{array}$ & $\begin{array}{c}-0.00 \\
(0.00)\end{array}$ \\
\hline GDP pc & $\begin{array}{l}-0.30^{* * *} \\
(0.08)\end{array}$ & $\begin{array}{c}-0.30^{* * *} \\
(0.08)\end{array}$ & $\begin{array}{l}-0.38^{* * *} \\
(0.09)\end{array}$ \\
\hline AIC & 2304.24 & 2302.65 & 2040.56 \\
\hline $\mathrm{R}^{2}$ & 0.03 & 0.03 & 0.04 \\
\hline Max. $R^{2}$ & 0.51 & 0.51 & 0.53 \\
\hline Num. events & 169 & 169 & 155 \\
\hline Num. obs. & 3295 & 3295 & 2822 \\
\hline Missing & 1296 & 1296 & 1769 \\
\hline PH test & 0.80 & 0.01 & 0.74 \\
\hline
\end{tabular}

${ }^{* * *} p<0.01,{ }^{* *} p<0.05,{ }^{*} p<0.1$.

Note: Aid as percentage of GDP results from dividing a country's foreign aid by its GDP. Democratic aid refers to the proportion of aid coming from democratic donors in a given year. US leverage is a continuous measure capturing the extent to which a country is dependent on the United States. The three variables have a one-year lag. 